\title{
A Machiavellian behavioural framing of social conflict risks in supply chains
}

\begin{tabular}{|r|l|}
\hline Journal: & Management Research Review \\
\hline Manuscript ID & MRR-01-2018-0022.R1 \\
\hline Manuscript Type: & Original Article \\
\hline Field Categories: & Other Management Related Topics \\
\hline Keywords: & realism, risk, analysis, managers, conflict, Machiavellianism \\
\hline \multicolumn{2}{|l}{} \\
\hline
\end{tabular}

\section{SCHOLARONE"}

Manuscripts 


\section{A Machiavellian behavioural framing of social conflict risks in supply chains}

\begin{tabular}{|c|c|c|}
\hline No & Comment & Response \\
\hline & \multicolumn{2}{|l|}{ Comment from reviewer 1} \\
\hline 1 & $\begin{array}{l}\text { I suspect that the paper is original and new but it does not } \\
\text { provide any significant information that would inform } \\
\text { supply chain managers as they work to improve the } \\
\text { performance of their supply chains to better satisfy the } \\
\text { ultimate customers of the supply chain. I can find very } \\
\text { little about supply chains or that relates to supply chains in } \\
\text { the manuscript. }\end{array}$ & $\begin{array}{l}\text { Thank you very much for this comment. In the revised paper, we have now } \\
\text { made substantial changes incorporating considerable supply chain } \\
\text { management literature. Mindful of our desire not to dilute the message, we } \\
\text { have focused our revisions which sought more explicit contextualisation of } \\
\text { our ideas in SCM literature at the introduction section of the paper. }\end{array}$ \\
\hline 2 & $\begin{array}{l}\text { The authors demonstrate knowledge of literature related to } \\
\text { the theories/philosophies that they discuss but very little } \\
\text { knowledge of the extant supply chain literature. }\end{array}$ & Please see our response above to comment no. 1. \\
\hline 3 & $\begin{array}{l}\text { The authors have sought to synthesize the theories and } \\
\text { philosophies through logical presentation and argument. } \\
\text { They have done a nice job of describing the theories and } \\
\text { philosophies but have done very little to relate them to } \\
\text { supply chains and supply chain management. }\end{array}$ & Please see our response above to comment no. 1. \\
\hline 4 & $\begin{array}{l}\text { Only discussion of the theories and philosophies with a } \\
\text { very tenuous connection to conflicts between supply chain } \\
\text { partners. The discussion is very general and provides no }\end{array}$ & $\begin{array}{l}\text { This point is also noted. We have addressed this comment by re-writing } \\
\text { the conclusion of the paper. In the revised conclusion, we now present a } \\
\text { separate sub-section for (i) theoretical contributions and (ii) practical }\end{array}$ \\
\hline
\end{tabular}




\begin{tabular}{|c|c|c|}
\hline & practical direction to supply chain managers. & $\begin{array}{l}\text { contributions. Section } 6.2 \text { which deals with practical contributions is } \\
\text { newly written text that directly responds to this comment. }\end{array}$ \\
\hline 5 & $\begin{array}{l}\text { I can see no implications for practicing managers or for } \\
\text { supply chain researchers. The approach taken is slightly } \\
\text { interesting but argument is not sufficiently developed to } \\
\text { tie the discussion to better understanding the dynamics of } \\
\text { personal relationships within a supply chain context. }\end{array}$ & $\begin{array}{l}\text { Thank you for this comment. We have addressed the issue of dynamics of } \\
\text { personal relationships in the paper by developing the literature in this area } \\
\text { in the (i) the newly created section } 1.1 \text { - where we discuss trust, } \\
\text { partnerships and collaboration (ii) we have created a new sub-section, that } \\
\text { is sub-section } 1.2 \text { which is explicitly directed at providing an overview of } \\
\text { these dynamics. }\end{array}$ \\
\hline \multirow[t]{2}{*}{6} & $\begin{array}{l}\text { The manuscript is well written from a stylistically } \\
\text { standpoint but not from a content viewpoint. There is } \\
\text { very little communicated that relates substantively to } \\
\text { SCM. }\end{array}$ & Please see our response above to comment no. 1. \\
\hline & Comment from reviewer 2 & +4 \\
\hline 7 & $\begin{array}{l}\text { You brought a different perspective by writing an original } \\
\text { idea in the study of SCM that are more practical in the } \\
\text { approach. I think it will be much better if the relationship } \\
\text { between the frame (machiavellianism) and SCM is } \\
\text { explored so that the conceptual idea resulted from the } \\
\text { paper can be contextually apply in SCM. Otherwise, the } \\
\text { result can be applied in any context and it will lose its } \\
\text { meaning. }\end{array}$ & $\begin{array}{l}\text { Thank you very much for this comment. We have addressed the need for } \\
\text { more explicit framing of Machiavellianism by the introduction of a revised } \\
\text { section } 1.4 \text { where we have drawn upon the works of Chonko (1982a, b). }\end{array}$ \\
\hline 8 & The originality of the paper is obvious. It offers an & Thank you for this comment. \\
\hline
\end{tabular}




\begin{tabular}{|c|c|c|}
\hline & $\begin{array}{l}\text { interesting approach to study SCM that may be still } \\
\text { uncommon for many supply chain scholars. Thus the } \\
\text { paper can contribute to methodological approach in the } \\
\text { area of study. }\end{array}$ & \\
\hline 9 & $\begin{array}{l}\text { A small note: the authors need to write the long version of } \\
\text { SCM at the first time it appears so readers do not need to } \\
\text { guess around what it stands for. }\end{array}$ & Thank you for this comment. This has now been addressed. \\
\hline 10 & $\begin{array}{l}\text { The authors presented exhaustively phylosophical } \\
\text { approach used in the study. They however elaborated } \\
\text { SCM as the context insufficiently and in-proportionately. } \\
\text { This can create ambiguity in some terms such as social } \\
\text { conflict risks, social threats, micro-political conflict } \\
\text { addressed by the authors. They may have specific } \\
\text { meaning in the context of SCM that differ from those in } \\
\text { other areas of studies. The authors seemingly assumed that } \\
\text { everyone already knows them (at least that's my } \\
\text { impression). }\end{array}$ & $\begin{array}{l}\text { Thank you for this comment. There are two issues which you have raised } \\
\text { which we will address. } \\
\text { As relates to the first part of your comment, the first reviewer in comment } \\
\text { no. } 1 \text { had also reiterated that there was an imbalance of supply chain } \\
\text { management literature against the philosophical writings. To address this } \\
\text { comment (which is also made here), we have extensively extended and } \\
\text { added SCM literature to the paper, especially in the introduction sections. } \\
\text { In terms of the second comment relating to terminology, we have } \\
\text { addressed this by articulating in the introduction section of the paper - } \\
\text { specifically in sub-section } 1.1 \text { (contextualisation) - what these terminology } \\
\text { means and implies. For example, we have now clarified that social conflict } \\
\text { are in effect, inter-personal conflicts. Furthermore, to avoid any confusion, }\end{array}$ \\
\hline
\end{tabular}




\begin{tabular}{|c|c|c|}
\hline & & we have completely removed reference to 'micro-political conflict'. \\
\hline 11 & $\begin{array}{l}\text { The arguments to apply Machiavellianism are well } \\
\text { presented. }\end{array}$ & Thank you for this comment. \\
\hline 12 & $\begin{array}{l}\text { The result that supply chain managers have to have two } \\
\text { behavioural patterns fails to show its contextual meaning. } \\
\text { It means that the result can be used in any other contexts, } \\
\text { such as decision-making or marketing management which } \\
\text { also involves complex relationship with many entities. } \\
\text { The emphasis on the context needs to be clarified. }\end{array}$ & $\begin{array}{l}\text { We now further emphasise that our theory is one of constructive } \\
\text { simplification in the realist tradition, which provides a starting point for } \\
\text { theory construction using the dark triad and conservatism/authoritarianism } \\
\text { literatures we outline. Hence we do not treat it as an essentialist theory } \\
\text { holding that managers need to have the two patterns. Of course, we thank } \\
\text { the reviewer for drawing to our attention the suggestion that this is how the } \\
\text { theory might be read, and therefore the abstract, as well as pages } 8 \text { and 11, } \\
\text { now further emphasise our concern with theory building through } \\
\text { constructive simplicity in the realist tradition. Also, we make further more } \\
\text { detailed comments throughout the paper drawing attention to the supply } \\
\text { chain context to ensure it is differentiated from alternative management } \\
\text { contexts where social relations and conflict are important, and where the } \\
\text { general theory might therefore similarly apply. For example, page } 17 \text { now } \\
\text { says more about the ideas that can bind supply chains (which the leonine } \\
\text { managerial type might be expected to promote). Furthermore, pages two to } \\
\text { four now establish the supply chain management context more clearly by } \\
\text { introducing new literature drawing attention to complexity and potential } \\
\text { for disruption in supply chain collaborations/partnerships. We did consider }\end{array}$ \\
\hline
\end{tabular}




\begin{tabular}{|c|c|c|}
\hline & & $\begin{array}{l}\text { introducing some of the substantial literature on micro-politics within } \\
\text { organisations, which might have served to differentiate the supply chain } \\
\text { context, but took the decision this would dilute the paper's focus } \\
\text { excessively. }\end{array}$ \\
\hline 12 & $\begin{array}{l}\text { The implications are more conceptual (as the paper is } \\
\text { intended to). However the practical implication can be } \\
\text { developed further in terms of how the suggested approach } \\
\text { can be used in SCM study. }\end{array}$ & $\begin{array}{l}\text { Thank you for this comment. This point was also raised by the first } \\
\text { reviewer and we have addressed it in our response to point no. } 4 \text {. In } \\
\text { summary, as we had stated (in response no. 4), in the revised conclusion, } \\
\text { we now present a separate sub-section for (i) theoretical contributions and } \\
\text { (ii) practical contributions. Section } 6.2 \text { which deals with practical } \\
\text { contributions is newly written text that directly responds to this comment. }\end{array}$ \\
\hline 13 & $\begin{array}{l}\text { The writing is phylosophically high indicated from the } \\
\text { choice of words and structure of the sentences. It is also } \\
\text { highly conceptual. These makes the paper is by nature } \\
\text { more suitable for only particular readers, that is those } \\
\text { having sufficient knowledge in methodological } \\
\text { philosophy, social science approaches, and SCM. Even } \\
\text { though due to its quality of the writing people can jump to } \\
\text { the conclusion and get the idea of applying behavioral } \\
\text { approach in studying SCM regardless the reasons } \\
\text { underlying the idea. }\end{array}$ & $\begin{array}{l}\text { This point is noted and a similar point appears to have been made by the } \\
\text { first reviewer in point } 4 \text { - thus, we have incorporated into the conclusion, } \\
\text { practical contributions of the paper - thus showing its application to SCM } \\
\text { practitioners. }\end{array}$ \\
\hline
\end{tabular}




\title{
A Machiavellian behavioural framing of social conflict risks in supply chains
}

\begin{abstract}
Purpose: This conceptual paper explores how supply chain manager's deal with social threats to supply chains ${ }_{2}$ in the process demonstrating the potency of a largely neglected strand of realist social theory. This theory, we posit, sheds a great deal of light on the behavioural reality of how supply chain managers operate within the social aspects of their risk environments.

Design/methodology/approach: The paper is presented as a narrative synthesis of classical realist sociological literature.

Findings: The Machiavellian approach provides a template which can be used to help academics and practitioners understand how and why supply chain managers orient themselves to the social threats they confront in very different ways. The theory's contention that the behavioural reality can be subdivided between two basic patterns allows it to serve as a constructively simple template for becoming attuned to ways in which supply chain managers socially construct and act within their social threat environments.
\end{abstract}

Research limitations/implications: The growing social complexity of supply chains gives behavioural responses a complexity reduction function. The authors theorise that such patterns, once activated, may not necessarily adapt rationally as guides to optimise the chance of success against the full range of social threats they are likely to encounter.

Originality/value: Cross-disciplinary supply chain management research is increasingly drawing upon sociology and behavioural science to facilitate greater understanding of not only the supply chain environment, but also of the roles of supply chain managers as relationship influencers and managers of conflict. The authors posit that Machiavellian-realist social theory can contribute to supply chain management scholarship by offering a constructively simple approach to evaluating the behavioural realities associated with social threats.

Keywords: realism; risk analysis; supply chains; social threat; Machiavellianism 
1.0 Introduction

\section{$\underline{1.1 \text { Contextualisation }}$}

The academic literature acknowledges that the management of risks is crucial to supply chains (Tang, 2006; Narasimhan and Talluri, 2009; Klassen and Vereecke, 2012; Freise and Seuring, 2015; Kilubi, 2016). A number of factors are driving this interest. One such factor is the ever increasing engagement and collaboration with international suppliers. Scholars such as Narasimhan and Talluri (2009) and Zeng and Yen (2017) point out that while such partnerships and collaboration have enhanced low cost sourcing, they have also increased the exposure of supply chains to disruption, in particular as associated supply chain relations have become more complex. In some instances, instead of representing desired platforms for co-operation, supply chains are experiencing competition between buying firms and their suppliers (Bradford et al., 2004; Rossetti and Choi, 2005). As they take into account the nature of the business environment and its relationships between organisations and key individual actors, supply chains represent complex social environments (Holweg and Pil, 2008; Kanda and Deshmukh 2008; Borgatti and Li, 2009). Thus, exploring risks emanating from social conflict between its key individual actors is of importance because of the impact of such conflict.

Within the context of supply chains, Bradford et al. (2004) defines conflict as “...the behaviours or feelings of interdependent parties in response to potential or actual obstructions that impede one or more of the parties achieving their goals" (p. 182). Conflict is widely recognised in the literature as a phenomenon ubiquitous to supply chains (see for example Bradford et al., 2004; Johnston et al., 2004; Lam and Chin, 2005; Kozan et al., 2006; Lam et al., 2007; Bradford and Weitz, 2009; Chang and Gotcher, 2010). Conflict can be classified against level, an example being personal or group level conflicts (Pelled and Adler, 1994; Pelled et al., 1999). It can also be classified against content (Guetzkow and Gyr, 1954). An example of such content-based social conflict could be inter-personal conflicts between various actors within supply chains.

Noting definitions of supply chain risks advanced by Juttner et al. (2003; p. 200) and Pfohl et al. (2010; p. 34), we conceptualise social conflict risk as "...risks within supply chains that are attributable to social (inter-personal) factors that have the potential to disturb and disrupt not only the flow of information, materials, products and services from the original supplier to the end user or customer, but also has the potential to impede on vendor-supplier-customer integration". More specifically, drawing from Bradford et al. $\mathrm{XXXX}$ 
(2004), we represent social (inter-personal) conflicts as conflict that emerges due to disagreements between key individual actors within (inter) supply networks. Such disagreements can arise out of distrust, suspicion, hostility among these actors. If unmanaged, the consequences for supply chains can be devastating, negatively impacting on optimised decision-making within the supply chain.

\subsection{Dynamics of social (inter-personal) relationships}

Individual managers play a critical role in the success of supply chains (van Hoek et al., 2002; Mangan and Christopher, 2005). For managers to be successful, there is an expectation that they exhibit expected level of both technical expertise and social skills. The literature suggests that such social skills will include not only the ability to engage in collaboration with other actors within the supply chain (van Hoek et al., 2002), but also an ability to build and maintain formal and informal social (personal relationships) and ties with other actors in the supply chain (Cousins et al., 2006; Gligor and Autry, 2012; Gligor and Holcomb, 2013). Being able to maintain such relationships and social ties in supply chains may be perceived to represent the foundation of SCM as social capital theory suggests that such relationships leads to increased familiarity between different supply chain actors, thus leading to an increase in the richness and quality of the dyadic exchange relationships (relational capital) between them (Gligor and Autry, 2012; Gligor and Holcomb, 2013). Drawing from the literature (Cousins et al., 2006), we can posit that through interaction, actors within a supply chain come to communicate the expectations and understand norms of other actors which leads them to taking a number of different actions. These actions may include (i) continuing to collaborate and in the process, reap a number of benefits which leads to value creation (ii) minimise the scale of engagement (iii) cease further engagement (iv) or in extreme cases take specific retaliatory threat responses against specific actors who are perceived to have violated behavioural expectations (see Chipulu et al., 2016).

\subsection{Managing social conflict risks}

While the literature widely recognises (i) the existence of conflict supply chains and (ii) a direct correlation between the effective management of social conflict risks and supply chain performance (Tang, 2006; Wagner and Bode, 2008; Rao and Goldsby, 2009), it appears that $\underline{\text { many organisations are far from able to effectively manage social conflict risks (Klassen and }}$ Vereecke, 2012; Freise and Seuring, 2015). There are a number of reasons for this. One $\mathrm{XXXX}$ 


\subsection{Bringing in a Machiavellian prism?}

The question therefore becomes how can, and more importantly from a behavioural perspective, how do, supply chain managers negotiate the 'social', or more specifically, the social threats that exist within the highly complex environments they seek to manage._More importantly, how can supply chain managers even begin to conceive the adaptivity or maladaptivity between a particular social conflict posture and a particular kind of social threat environment? We will see that ultimately a realist perspective may be of value in evaluating social conflict in such ecological terms. We focus on the supply chain manager, for while there are numerous actors involved in supply chains (Reinecke et al., 2018), the supply chain manager role remains the critical (van Hoek et al., 2002) and pivotal (Mangan and Christopher, 2005) dimension of success in the management of supply chains (van Hoek et al., 2002). 
To address these questions, and noting the view that there is a tendency for SCM studies to be undertaken in a positivist manner which has more often than not, led to the human behavioural dimension of SCM being ignored (see Tokar, 2010; Wieland et al., 2016; Schorsch et al., 2017), in this study, we seek to utilise cross-disciplinary epistemologies, theories and philosophies. The intention underlying this is not just to address the questions at hand, but more fully to increase the "robustness, predictive accuracy and overall usefulness" (Tokar, 2010, p. 89) of academic theory on SCM risk management. Our approach should not come as a surprise as Huo et al. (2015) points to the human behaviour dimension of SCM playing a critical role in supply chains. Adamides et al. (2012) reminds us that supply chains are primarily social constructs, entailing that processes of social construction undertaken by supply chain managers should be important objects of study. Furthermore, as Granovetter (1985) posits, economic activity is generally "embedded in concrete, ongoing systems of social relations" (Granovetter, 1985; p. 487). Hence, our approach, entailing a focus on how social relations which traverse the social threat environment are socially constructed, is likely to further equip SCM with knowledge and insight beyond its traditional frontiers_-(Stock, 1997, 2009; Stock et al. 2010; Tokar, 2010; Knemeyer and Naylor 2011).

As such, this study responds to a specific question raised by Khan and Burnes (2007, p. 211): "How [do] other disciplines of research on risk inform our understanding of risk in the supply chain?". In response to this question, the authors show how one such classical philosophical theory, 'realism' (Devitt, 1991; Sayer, 2000; Reed, 2008), has increasingly been harnessed by scholars to expand the frontiers of SCM scholarship (Aastrup and Halldorsson, 2008; Adamides et al., 2012; Peters et al., 2013; Rotaru et al., 2014).

We argue that there is still ample opportunity for further exploration of realist ideas which might enhance our understanding of SCM. Our focus is on realist ideas pertaining to how social actors both socially construct and (mentally) reduce the complexity of their social threat environments, and in particular how they envision tactical possibility within such environments. To achieve this focus we refer to a largely neglected strand of realist social theory mainly associated with the Italian Renaissance philosopher Niccolo Machiavelli

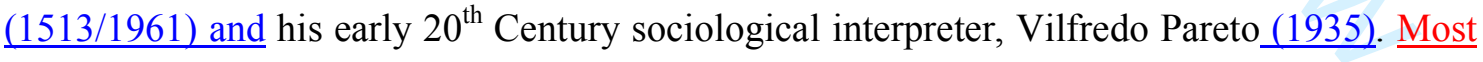
importantly, this strand of theory focuses on the timelessness of human nature and its psychological expressions within highly permanent behavioural postures, considering also the power play and social relations environments produced by these postures. Thus, the work of Niccolo Machiavelli (1513/1961) and Vilfredo Pareto (1935) will provide us with realist $x x x x$ 
impetus for articulating how supply chain managers may both create, and yet also understand and overcome, social factors arising from human nature that can sometimes threaten the integrity of supply chains.

Behavioural as opposed to normative or instrumentally rational models of human behaviour have given philosophical and psychological realism its subject matter down the centuries, in particular from Machiavelli onwards. Interest in behavioural reality, albeit to some extent divested of Machiavelli's grim views of human nature, has persisted and burgeoned in recent years in the form of behavioural finance and economics. It has also permeated more recent general management scholarship (Cox, 1999; Bendoly and Schultz 2006; Tokar, 2010; Stank et al., 2011; Croson et al., 2013; Katsikopoulos and Gigerenzer 2013). More specifically, within SCM scholarship, scholars such as Chonko (1982a) have claimed that an element of Machiavellian psychological orientation may be indispensable for managers engaged in bargaining. This contention, which of course has implications for diverse management fields, is undergirded by voluminous psychological literatures, spanning psychometrics and evolutionary psychology, which all relate to 'Machiavellianism' as a tactics-oriented psychological expression of human nature which can also be studied psychometrically as an important individual difference. Christie and Geis (1970), who made $\underline{\text { the greatest founding contribution to this literature, posited that individuals demonstrating a }}$ high-level of Machiavellian tactics, values and morality (i.e. 'high Machs') were more likely to out bargain those with lower orientation levels (i.e. 'low Machs'. The crux of the difference, they argued, lay in 'high Machs' being relatively less possessed of the feelings of empathy which normally prohibit manipulation in interpersonal relationship contexts. Taking this view, they expressed grudging admiration for Machiavellians on account of their more flexible approach to making, maintaining, modifying and breaking social relations. Accordingly, some SCM literature (Chonko, 1982a, b) has discerned a positive relationship between Machiavellianism and successful supply channel performance; nonetheless scholars $\underline{\text { such as Dion and Banting }(1987,1987) \text { did not find any such relationship. }}$

Despite these suggestions of upside within Machiavellianism, the main contribution of behavioural perspectives to management arises from their concern to explore weaknesses within managerial decision making. Croson et al. (2013, p. 1) emphasise that such studies must be rooted in 'reality'. In the context of our study, this entails piercing the reputational veils supply chain managers like to place over their private thoughts and actions, and exposing these to the light of day. However, as such subject matter may often prove $x x x x$ 
inaccessible for empirical research, realist researchers must base their investigations on sometimes contestable general assumptions concerning human nature and common patterns found in its psychological expressions. More specifically, behavioural studies informed by the realist tradition are likely to emphasise that managers often have good intentions, but are constrained by 'human nature' itself; in effect, by their innate behavioural propensities, or by what is sometimes termed their 'animal spirits' (Keynes, 1936, pp. 161-163). A theory of 'animal spirits' (that is, innate urges to activity) that produce highly permanent social conflict postures is exactly what Machiavelli offers us.

It is commonly $\operatorname{argued}_{2}$ and just as commonly forgotten ${ }_{2}$ that viewing behaviour through this Machiavellian prism is both ethical and necessary because each illumination of a Machiavellian behaviour simultaneously facilitates counter-Machiavellian reflection, scrutiny and appraisal. Correspondingly, our rationale for applying this theoretically troublesome strand within behavioural science to SCM contexts is that it may help individual supply chain actors better appreciate how and why they and others behave as they do (Chonko, 1982a, b). Crucially, such understandings can also feed through into the more enlightened design of supply chain processes (Croson et al., 2013; Katsikopoulos and Gigerenzer, 2013).

\subsection{Methods and philosophies}

As a methodological approach, we adopted a novel critical analytical approach which involved narrative synthesis. According to Popay et al. (2006, p. 5), this approach involves a review and synthesis of findings drawn from multiple literatures. For this reason, scholars generally regard narrative synthesis as an appropriate means of presenting summation of theory (Greenhalgh et al., 2005; Oliver et al., 2005; Leamy et al., 2011; McDermott et al., 2013). Thus, the outcome of narrative synthesis which involves synthesising literature from various sources is usually a form of understanding of the current knowledge in relation to particular phenomenon.

We argue that the phenomenon that interests us, that is, social construction of social threats in supply chains and associated managerial behaviour, is perhaps most appropriately explained by realist social theory. In doing so, we are able to bring together ideas at an appropriate and useful state of abstraction to support our drawing broad behavioural conclusions. Our approach will be to argue, from the psychological realism of Machiavelli $\underline{\text { and Pareto, }}$ that it can be a useful exercise to categorise supply chain managers in terms of which 'animal spirit' controls their social conflict imagination, and their related behaviours. $x x x x$ 
We will argue that two such 'animal spirits' matter.may Working with this constructively simple metaphor, supply chain managers can be viewed as varying in terms of which one of two very different behavioural patterns, activated by social threat is operative. The contention will be that each pattern lead them to structure social threat in particular ways, against particular priorities, all of which reflects the operation of an underlying animal spirit whose essential role is to reduce the complexity of how the managers in question perceive themselves and their social conflict environments.

Noting guidance from Popay et al. (2006) on the conduct of narrative synthesis, our methodological approach involved the following steps. Firstly in order to establish what literatures to review and at the same time undertake an assessment of the applicability of the review findings (Jagosh et al., 2011), we undertook an iterative purposive sampling of references and theoretical publications on realism and supply chain risks. This process was undertaken independently by two of the three authors with outcomes compared at the completion of this process. Secondly, we undertook (as we reviewed literature) an assessment of each reviewed article for not only relevance, but also for use of appropriate theory.

\subsection{Realist Philosophy}

\subsection{Cross-disciplinary philosophies}

Realism is of particular interest to the SCM discipline because increasingly, there is a recognition that supply chains are interactions and activities that are enacted by multiple social actors (stakeholders, suppliers, purchasers, the supply chain manager) that may maintain multiple and conflicting interpretations and perspectives of a particular reality (Kanda and Deshmukh, 2008).

It is therefore through our understanding of how these realities and subjectivities are interpreted that we as observers and commentators may be able to approach the objective reality of supply chains. The theory derived from such an observation suggests that supply chain managers are similarly exposed to social threats arising both within their organisations and across inter-organisational fault lines. Specifically, we have in mind conflict arising typically not just from manifest loss of commitment among individual actors of the supply

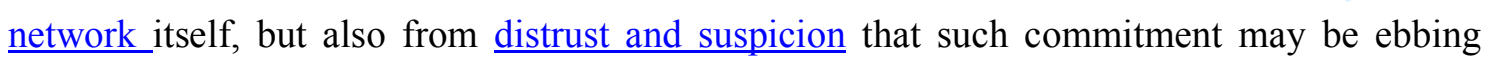
(Daugherty, 2011). Crucially, this entails that we are concerned with the very private thoughts and feelings $\underline{\mathrm{SCM}}$ managers have about partners who they have to collaborate and

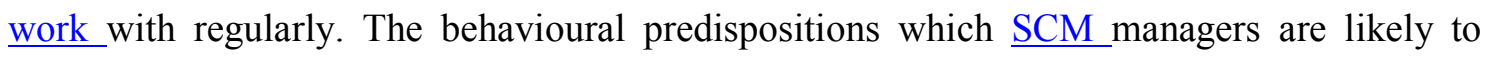
$\mathrm{XXXX}$ 
bring to these interactions, we suggest, are likely to simplify down to their basic ingredients and exert more influence on behaviour whenever tensions rise within the network, and especially whenever managers are also relatively unfamiliar with one another (such that interpretive templates become more necessary).

Such periods of raised tension, we suggest, are likely to include decision contexts whenever supply chains are on the verge of reconfiguring, and whenever managers act to ensure that supply chains deliver improved financial results and better meet the expectations and preferences of various upstream and downstream stakeholders against the increasingly challenging backdrop of quickening product cycles and enhanced low cost sourcing.

\subsection{Articulation of realist philosophy}

Machiavelli's famous (1513/1961) articulation of realist philosophy referred to behavioural reality as 'the effectual truth of things'; something he said we should differentiate carefully from the 'imagination' of these same things. Since then realism has flourished as a philosophy concerned with overcoming mind dependency problems to reveal truth (see for example, Wild, 1947), a concern which risk researchers such as Starr (1980) and Thompson $(1986,1990)$ have famously articulated in terms of the need to study risk in both its objective and socially constructed aspects. In SCM research, this same concern finds expression in calls by scholars such as Peck (2005), Adamides et al. (2012) and Peters et al. (2013) to understand and overcome managerial biases. Correspondingly, it is clear that social construction and social amplification of risk within supply chains constitute a vital study topic. Like other managers, supply chain managers, even those professing to have an expertise in risk management, often reveal biases (Wynne, 1989) risk-attenuation effects (Merkelsen, 2011) and Machiavellian behaviour (Chonko, 1982a, b). Further criticism comes from sociocultural perspectives of risk perception which emphasise cultural optics as major causes of realist mind dependency problems (see Lupton, 1999; Taylor-Gooby and Zinn, 2006; Peters et al., 2013). Realist theorists can argue that all such criticism and dispute merely underscores the existence of frailty within human perception and judgment out of which the need for realist research leading to appraisal and improvement of human judgment arises in the first place. From this standpoint, all the achievements of heuristics-and-biases literatures in identifying gaps between descriptive and normative models of reasoning reflect Machiavelli's much earlier combative position underscoring the immense mental challenge of discerning 'the effectual truth of things'. 
A review of literature (Devitt, 1991; Reed, 2008; Button, 2013), suggests that realist researchers and scholars struggle with philosophical dispute over how objective representations of the social world can ever be. They assess theory not just for its fit with empirical evidence, but also for the reality of what it purports to existence, that is $\underline{\text { its }}$ ontological plausibility (Chang, 2001). An expectation that social theory can imitate natural science through recourse to ultimate units that conserve themselves over time exposes some realist scholars to the accusation that their reliance on abstract descriptive categories is insensitive to social reality (Fine, 1984). Accordingly, many late-20th-century scholars known for their broad scepticism to any view of the existence of an absolute truth have regarded realists as ensnared by the particular mind dependency problem that is their uncritical essentialist commitment to the social constructs they use. These scholars however, according to Lopez and Potter (2001), can expect to be reminded by today's critical realists that what matters is to reduce these problems over time. In other words realism can comfortably propose constructively simple theoretical templates such as the ones offered in this paper, on the clear understanding that while these supply appropriate starting points for theory construction, they should always be subject to further refinement through critical scrutiny and having their mettle tested. The realism which we find in Machiavelli's works fits well with these incrementalist sensibilities that have come to characterise contemporary realism. Its theoretical constructions, as we will articulate in the next section, are set out in extremely simplistic terms; specifically, as a theory of animal spirits which reduces complex psychological patterns to simple animal caricatures. We suggest that Machiavelli's constructive simplicity offers useful first approximations allowing realist inquiry to remain acutely aware of its limitations, while at least beginning to rise to the challenge of exploring the adaptive fitness of particular behavioural postures to particular social conflict environments. We will try to show that although Machiavelli's first approximations concerning both are vague; they provide a viable platform for ecological risk theory construction from the standpoint of SCM risk research.

\subsection{Ecological rationality}

Within this context, we present Machiavelli as linking all the necessary basic ingredients that permit us to interpret him as a theorist who allows us to use ecological rationality as a criterion for evaluating the behaviour of supply chain managers. Ecological rationality is conventionally traced back to Brunswik (1943) who suggested that human cognition and $x x x x$ 
behaviour only make sense in real world environmental niches which are inherently uncertain and probabilistic in nature - just like the social conflict risk environments we conceive of here. Another proponent of ecological rationality is Simon (1990), who viewed 'bounded' human rationality as akin to a pair of scissors, where the two bounds on our rationality are the structure of the task environment and the computational capabilities of the actor. More recent work on ecological rationality has been undertaken by Gerd Gigerenzer and other members of the Adaptive Behaviour and Cognition (ABC) research group. Here the challenge became to understand how simple cognitive mechanisms can either be rational or irrational. Rational behaviours 'fit the demands and structure of particular environmental niches' (Bullock and Todd, 1999); irrational ones 'operate outside their proper niches' (Seth, 2002). Todd and Gigerenzer (2007) clarify the ontological foundations for this research programme by suggesting that it encompasses two blades matching the blades of Simon's scissors. One is explanatory. It employs theoretical and experimental methods to study the mind's 'adaptive toolbox' of decision mechanisms. The other is normative and seeks to evaluate the rationality of these mechanisms by using methods such as computer simulation and mathematical analysis to establish precisely what environmental structures enable these mechanisms to produce better than chance outcomes. This is philosophically and methodologically far more sophisticated than the theory of animal spirits proposed by Machiavelli; nonetheless the social theory he offers us deserves to be read with exactly these concerns to the fore.

In asking what environmental cues decision mechanisms can match to, Todd and Gigerenzer (2007) suggest these can exist as 'patterns' right across physical, biological, social and cultural (including institutional) realms. They include patterns within the social world which as a species we have learned to recognise and be simultaneously 'ecologically rational' and 'evolutionarily rational' towards, because they have challenged us in our environments of evolutionary adaptation. This is exactly the ontological foundation we attribute to the Machiavellian realist theory we develop in our paper. As John Maynard Keynes (1936; pp. 161-163) put it, 'our rational selves allow us to choose between alternatives as best we are able, calculating where we can'. Yet despite our best efforts, we often 'fall back for our motive on whim, sentiment or chance'. It is within this context that Keynes made the point that our innate urges to activity that is, our animal spirits motivate many of our decisions. Working from this quote from Keynes (1936), Zinn (2008), exploring

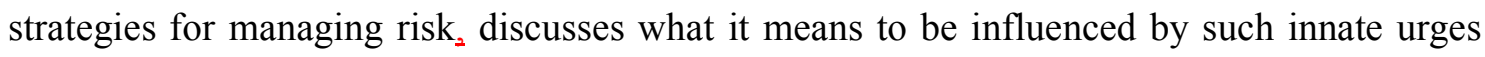
toward activity. He advises that if we are to understand everyday strategies of risk and $x x x x$ 


\subsection{Social theories}

\subsection{Machiavelli}

Machiavelli's (1513/1961) 'The Prince' argued that enduring human nature churns out common behavioural patterns that can determine whether leadership will succeed or fail. His approach was to evaluate these patterns in terms of their appropriateness for the times; hence we can read him as a theorist concerned with ecological rationality. Machiavelli reasoned that enduring human nature must underlie certain behavioural patterns where these repeat endlessly down the centuries. To know history is to be capable of learning from the mistakes of the past, yet to be human and in the predicament of the decision-maker is to find this sort of reflective learning extremely difficult if not wholly impossible. We can call such an assumption of what is conceived as pervasive cognitive entrapment emanating from rigid mind-sets as Machiavelli's 'behavioural realism'. Most importantly, Chapter XVIII of 'The Prince' requires us to view this problem as one of stubborn innate urges. The chapter opens with Machiavelli advising that Princes wishing to gain and maintain power should choose between two innate urges. These are well qualified to be expressed in constructively simple terms as 'animal spirit' guides because unlike most behavioural economics/finance theories of animal spirits they actually employ animal caricature. Sometimes Princes must be lions who use aggression to 'fright away the wolves'. At other times they must be foxes who use guile (which we can also link to the 'Machaivellianism' studied by Christie and Geis, 1970) to 'avoid the snares'. Machiavelli despairs that whereas ideal Princes can be both lion and fox simultaneously, using both aggression and guile as circumstances require, real Princes usually remain stuck with just one of these mental and behavioural sets. Princes face a difficult task in cultivating the mental flexibility whichth Machiavelli advocates they should struggle towards. He contends that if they try, they may outmanoeuvre less flexible rivals. $x x x x$ 
This simple passage implies much more than it says. Human nature here is a bestiary of 'lions' and 'foxes' - a constructively simple representation of patterns which, we will soon see $_{2}$ do seem to have a solid basis in reality. We also have two very different social conflict environments comprising 'wolves' or 'snares'. In the context of our study, this begs two questions: are Machiavelli's 'snares' the trust-based interpersonal loyalties upon which supply chain network persistence depends, yet which may increasingly have to be broken? And are Machiavelli's 'wolves' the wolves (e.g. market competitors) that begin to circle when they sense supply networks are beginning to break down, and who might wish to redirect them through their own companies, either to better meet their own business needs or to otherwise derive competitive advantage through their increasing control of socially available supply chain resources? These are exactly the social conflict risks we think are most important for supply chain managers, and so we think an application of Machiavellian behavioural theory is highly apt. Within that context we ask: in what ways might Machiavelli's vulpine (fox-like) patterns allow supply chain managers to 'avoid the snares?; in what ways might leonine (lion-like) patterns allow them to 'fright away the wolves'? We think this crude ecological discourse, penned initially in the $16^{\text {th }}$ century, asks big questions and provides an important springboard into theory construction today.

\subsection{Pareto}

Approximately five centuries after Machiavelli (1513/1961), the sociologist Vilfredo Pareto (1935) used Machiavelli's two innate predispositions as the foundation for his sociological theory (Marshall, 2007, p. 21-25 and 116-133). He considered these 'inherited behavioural traits' (Pareto 1935: §1845). The leading commentator to have written on Pareto is Joseph Lopreato (Lopreato, 1980; Crippen and Lopreato, 1989) whose sociobiological reading gets us_closer to appreciating why these patterns may be encoded in human DNA, such that they are always 'latent' within human nature yet capable of activation under certain circumstances (i.e. vulpine patterns may be activated in social threat contexts comprising the 'snares' we mentioned above; leonine patterns may be activated in rather different social threat contexts comprising the 'wolves' we mentioned above'. Crippen and Lopreato (1989) contend that Pareto's theory of how vulpine and leonine patterns alternate in leaders is well supported in the modern sociobiological concept of a seesaw evolutionary strategy. According to this theory, as a species we developed vulpine patterns, capable of periodic activation from latency in human nature to help communities cohere and prosper during times of social flux $x x x x$ 
and complexification. Here vulpine patterns were beneficial because fluid social relations served the overall needs of these societies more than rigid ones; similarly, we developed leonine patterns, capable of activation from latency to help societies cohere and survive through social solidarity and common binding ideology during times of scarcity ${ }_{2}$ austerity, war, and other passing crises.

If this theory is correct, then the contemporary problem for supply chain managers becomes plain and can be stated simply. The theory implies that each pattern might always exist at some 'level', most likely in inverse proportion to the level of its counterpart, in conceivably the personality of every supply chain manager. If they, like the rest of us, are really hardwired to 'stick' with just one of these patterns disproportionately, then how can they give adequate attention to the full range of social conflict risks they need to consider within supply chains, where both 'snares' and wolves' are always likely to be present as categories of hidden social threat that matter?

\subsection{Are these patterns real?}

Based on earlier works on psychological conservatism by Wilson and Patterson (1970) and on right wing authoritarianism by Altemeyer (1981), Marshall (2007), Marshall and Guidi (2012) and Marshall and Ojiako (2015) argue that the Machiavellian-Paretian 'lion' equates today's conservative and authoritarian behavioural patterns. As Marshall (2007) points out, both conservative and authoritarian patterns display similar strong positive correlations with measures of dogmatic and rigid thinking, as well as similar strong negative correlations with measures of openness. Much literature (Knight, 1999) emphasises the strong overlap between conservative and authoritarian patterns. Accordingly, both Johnston et al. (2004) and Brinkhoff et al. (2015), suggest that (what we might call 'leonine') honesty and conscientiousness in supply chain management interactions can lead to the development of trust, commitment and mutual respect which can mitigate against the adverse impact of suspicion and hostility among key SCM actors.

Crucially, then, many conservatism-authoritarianism studies serve to validate and enrich our understanding of the pattern Machiavelli once equated with the 'lion'. For the purpose of the present study, we can regard this pattern's emphasis on ideological commitment and persistence as a psychological strategy of social conflict management which seeks to promote ideology and group affiliation as a social cement. Its effect, we further suggest, might sometimes beis to shore up trust and mutual commitment across social groups, where $\mathrm{XXXX}$ 
complex global supply chains_(Johnston et al., 2004; Johnson et al., 2018) become constitutive of such groups.

What we call 'vulpine' managerial patterns can arguably be viewed as undermining such trust and commitment, yet this claim must be carefully qualified to recognise qualities of charismatic leadership and manipulation that might achieve the reverse, at least over the short term until the true nature of the pattern is understood. Marshall (2007) and Marshall and Guidi (2012) argue that the Machiavellian-Paretian 'fox' equates to today's 'dark triad' leader or manager, whose related literature permits the above ambiguity to be explored. This well-known pattern comprises manipulative behaviours (from Machiavellianism), lack of empathy (from psychopathy) and the excessive preoccupation with admiration, status and prestige (from narcissism); with all three constructs overlapping into what Paulhus and Williams (2002) first termed the 'dark triad'. Growing evidence suggests that the three constituents of the dark triad are all intensifying in management as social relations not just within organisations (see Galperin et al., 2010; Harms et al., 2011) but across entire supply chains due to financial performance and profitability challenges (Lingnau and DehneNiemann, 2015). Although many management academics are aware of this important psychosocial trend but know it from separate literatures dealing with the rise of narcissistic (Maccoby, 2003; Higgs, 2009), psychopathic (Babiak and Hare, 2007; Boddy, 2011) and Machiavellian behaviour (Jakobwitz and Egan 2006) within the modern organisation, our contention is that there appears to be very limited awareness or focus of this trend in SCM scholarship. Clearly, this behavioural pattern is, as Machiavelli and Pareto seemed to appreciate, the very antithesis of the leonine one. Nowhere to be seen is the ideological commitment that provides social cement during times of crisis where for example, either competition between buying firms and their suppliers or opportunistic behaviour within the supply chain threatens the viability of exchange relationships. Instead the emphasis is on individual guile and lack of empathy among specific SCM managers, which makes it possible

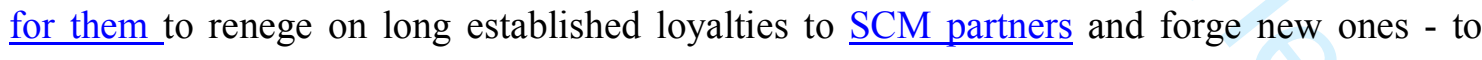
which they are able to convincingly feign commitment. Also important here is a resistance to the internalisation of all socially binding ideologies, which also renders these SCM managers more open to the reconfiguring of existing (social) relations within the supply chain, and to the establishment of new binding ideologies, as new needs and interests arise.

Authoritarian worldview has typically between represented as viewing the social world as a 'competitive jungle' (Duckitt, 2001) filled with 'animals which either eat or are $x x x x$ 
eaten' (Lowenfeld, 1945). Exactly the same has often been said of Machiavellians (Christie and Geis, 1970) and narcissists (Horny, 1950). And this worldview is also strongly implied in studies finding psychopaths unlikely to possess 'just world beliefs' (see Hafer et al., 2005). What we might credibly surmise about 'leonine' and 'vulpine' managerial patterns, then, is that both can be viewed as psychological expressions of human nature which for the most part remain dormant, but which may grow more salient as influences on thought and behaviour whenever social relations spanning complex supply chains grow strained and discordant.

\subsection{Conclusion}

The purpose of this conceptual paper is simple. It introduces a Machiavellian-realist framework for evaluating the behavioural realities of how supply chain managers deal with social threats always present right across global supply chains. Machiavelli and Pareto lead us

to become aware of some obviously important social threat risk factors for SCM which might otherwise be neglected.

\subsection{Theoretical contributions}

Working within the framework they offer, we can see that supply chain managers always need to negotiate 'snares'. There are always loyalties to persons, commitments to both formal and informal agreements, and indeed to ideological perspectives such as beliefs in the strategic necessity of particular supply chain networks, that sometimes have to be overturned. What's more, 'foxes', i.e. Machiavellians, narcissists and corporate psychopaths, who we know exist in abundance in modern organisations, are exactly the sorts of managers who we can expect to excel in these tasks which many others may recoil from as emotionally tumultuous and beyond all realistic consideration. Likewise, our framework focuses attention on the obvious fact that there are always 'wolves' to be reckoned with when scoping social conflict risks across supply chains. Clearly, a supply chain weakened by distrust and loss of commitment is one ripe for strategic resource-grabbing by competitors. Leonine patterns, i.e. conservative authoritarian ones, can be adaptive here by building trust and loyalty on personal levels, and by perpetuating and amplifying binding ideologies of long term organisational partnership, stakeholder value, reputational management and ethical integrity that, taken together, can ensure supply chains are maintained.

Even if it is doubted, despite the modern psychological literatures we have mentioned, 
that such stable and enduring personality patterns are commonplace and can each be expected to produce limited and insufficient views of social conflict risks to supply chains, it can still credibly be argued with reference to our framework that our two patterns may correspond to temporary 'states' as opposed to more permanent 'traits' that temporarily grow salient as guides to social conflict negotiation during times when social threats intensify and stoke anxiety. Both our patterns are perhaps often _activated' from latency within enduring human nature by anxieties arising through social interaction which cause exactly the same misanthropic view of human nature to take root and begin to cause some paranoia in the minds of managers. The very different behavioural strategies of leonine and vulpine managers might then proceed from this common psychological base.

\section{$\underline{6.2 \text { Practical implications }}$}

By not traditionally accounting for social threats to supply chains, SCM scholarship has been limited in terms of its ability for foster an understanding of the reasons behind specific managerial behaviour (Gligor and Autry, 2012; Gligor and Holcomb, 2013). Thus, studying the behavioural reality of how supply chain managers operate within the social aspects of their risk environments may permit academics to service the need for practitioners to gain an understanding of the very different individual behavioural realities that matter within supply chains. For the individual actors, thisit implies a need to focus more on open and upfront $\underline{\text { negotiations aimed at building clarity on both formal and informal behavioural expectations }}$ in the relations between supply chain managers. It is only through such open negotiations that managers can articulate, take into account, and mitigate against, social threats to supply chains which originate from very different managerial approaches to dealing with conflict.

\subsection{Concluding remarks}

To conclude, one could argue that the management of supply chains was at a certain point in time simple and straightforward. Arguably, the flow of products and services commenced relatively un-impeded from the point of source of raw materials and resources ending up with customers taking possessing of these goods and services. The reality however is that nowadays $_{2} \div$ supply chains and their management are rather more complicated. Their management has become more social in nature, even faster than it has become more technological; moreover even technological leaps such as incorporation of the internet of things' within supply chain management has brought with it new social coordination $x x x x$ 
challenges-: According to Cox (1999), supply chains represent “... a spaghetti web of complex interconnecting relationships" (p. 211). Supply chains often encompass inter-organisational and cross-functional processes, thereby adding to the management coordination challenges they pose (Flynn et al., 2010; Stank et al., 2011; Ellram et al., 2014). To be efficient and effective, the flow of information, services, finance and products needs to be co-ordinated between resource providers, suppliers and customers by managers with not only excellent people and relationship-building skills (Sharif and Irani, 2012; Youn et al., 2012), but also with cross-functional and organizational judgement and decision skills fit for dealing with a host of contemporary management issues that may include forecasting, planning and risk management (Juttner, 2005; Murphy and Poist, 2007; Sandberg and Abrahamsson, 2010). In terms of risk, the challenge is for SCM managers to be able to not only identify and assess likely risks and their possible impact upon the supply chain, but to be able to competently assess operational vulnerabilities arising from risks that exist both within ${ }_{2}$ and external to $_{2}$ the supply network. Juttner (2005) thus regards risk decisions in supply chains as predominantly concerned with managing the trade-off between the performance of the supply chain and its vulnerability. Such vulnerabilities are particularly pronounced at present as prevailing economic conditions continue to drive global sourcing, thus leading to often longer and more complex supply chains at the same time as product cycles are declining.

The main arguments put forward in this paper are that realist risk research tends not to rise to the challenges posed by such growing complexity and the managerial strain it creates within supply chains. Instead it navigates relatively safe channels focussing on risks and responses that manifestly have objective existence and allow for little if any perceptual distortion. Our paper asks realist risk research to re-engage with the spirit of early realist inquiry that was prepared to indulge in ontological speculation about what 'things' really exist and matter, applying this concern to the complex world of supply chains. We suggest that a realist ontology of evolutionary conflict environments linked to innate urges (animal spirits)_which orient managers towards social conflict in supply chain management today, should help facilitate a greater appreciation among scholars on how human nature influences the social construction and management of conflict by supply chain managers in highly varied cultural and indeed cross-cultural supply chain contexts around the world.

\section{References}


Aastrup, J. and Halldorsson, A. (2008), "Epistemological role of case studies in logistics: a critical realist perspective", International Journal of Physical Distribution \& Logistics Management, Vol. 38, No. 10, pp. 746-763.

Adamides, E., Papachristos, G. and Pomonis, N. (2012), "Critical realism in supply chain research: Understanding the dynamics of a seasonal goods supply chain”, International Journal of Physical Distribution \& Logistics Management, Vol. 42, No. 10, pp. 906930.

Altemeyer, R. (1981), Right Wing Authoritarianism. Winnipeg: University of Manitoba Press.

Babiak, P. and Hare, R. (2007), Snakes in Suits: when psychopaths go to work. HarperCollins, New York.

Bendoly, E. and Schultz, K. (2006), "Incorporating behavioural theory in OM empirical models", Journal of Operations Management, Vol. 24, No. 6, pp. 735-863.

Boddy, C. (2011), "The Corporate Psychopaths Theory of the Global Financial Crisis", Journal of Business Ethics, Vol. 102, pp. 255-259.

Borgatti, S. and Li, X. (2009), "On social network analysis in a supply chain context", Journal of Supply Chain Management, Vol. 45, No. 2, pp.5-22.

Bradford, K., Stringfellowb, A. and Weitzc, B. (2004), "Managing conflict to improve the effectiveness of retail networks", Journal of Retailing, Vol. 80, 181-195.

Bradford, K. and Weitz, B. (2009), "Salespersons' management of conflict in buyer-seller relationships", Journal of Personal Selling \& Sales Management, Vol. 29, No. 1, pp.25$\underline{42 .}$

Brunswik, E. (1943), "Organismic Achievement and Environmental Probability", The Psychological Review, Vol. 50, No. 3, pp. 255-90.

Bullock, S. and Todd, P. (1999), "Made to Measure: ecological rationality in structured environments", Minds and Machines, Vol. 9, No. 4, pp. 497-541.

Button, T. (2013), The Limits of Realism. Oxford University Press. 
Brinkhoff, A., Özer, Ö. and Sargut, G. (2015), “All You Need Is Trust? An Examination of Inter - organizational Supply Chain Projects", Production and Operations Management, Vol. 24, No. 2, pp.181-200.

Chang, H. (2001), "How to take Realism beyond Foot-Stamping”, Philosophy, Vol. 76, No. 1, pp. 5-30.

Chang, K. and Gotcher, D. (2010), "Conflict-coordination learning in marketing channel relationships: The distributor view", Industrial Marketing Management, Vol. 39, No. 2 , pp.287-297.

Chipulu, M., Ojiako, U. and Marshall, A. (2016), "Consumer action in response to ethical violations by service operations firms: The impact of heterogeneity", Society and Business Review, Vol. 11, No. 1, pp.24-45.

Chonko, L.B. (1982a), “Are purchasing managers Machiavellian?”, Journal of Supply Chain Management, Vol. 18, No. 4, pp.15-20.

Chonko, L. (1982b), "Machiavellianism: Sex differences in the profession of purchasing management", Psychological Reports, Vol. 51, No. 2, pp.645-646.

Christie, R. and Geis, L. (1970), Studies in Machiavellianism. Academic Press, New York.

Cousins, P., Handfield, R., Lawson, B. and Petersen, K. (2006), "Creating supply chain relational capital: the impact of formal and informal socialization processes", Journal of Operations Management, Vol. 24, No. 6, pp.851-863.

Cox, A. (1999), “A research agenda for supply chain and business management thinking”, Supply Chain Management: An International Journal, Vol. 4, No. 4, pp. 209 - 212.

Crippen, T. and Lopreato, J. (1989), “Pareto's “The Transformation of Democracy” and Modern Political Theory”, Revue Europeene des Sciences Sociales, Vol. 27, pp. 47-86.

Croson, R., Schultz, K., Siemsen, E. and Yeo, M. (2013), "Behavioural operations: the state of the field", Journal of Operations Management, Vol. 31, No. 1, pp. 1-5. 
Daugherty, P. (2011), "Review of logistics and supply chain relationship literature and suggested research agenda", International Journal of Physical Distribution \& Logistics Management, Vol. 41, No. 1, pp. 16-31.

Devitt, M. (1991), “Aberrations of the realism debate”, Philosophical Studies, Vol. 61, No. 1, pp. 43-63.

Dion, P. and Banting, P. (1988), "Industrial buyer-supplier negotiations", Industrial Marketing Management, Vol. 17, pp. 43-47.

Dion, P. and Banting, P. (1987), "Effective Buyers: Are they cunning or cooperative?", Journal of Supply Chain Management, Vol. 23, No. 4, pp.26-31.

Duckitt, J. (2001), “A Dual Process Cognitive-Motivational Theory of Ideology and Prejudice”, Advances in Experimental Social Psychology, Vol. 22, pp. 41-113.

Ellram, L. and Cooper, M. (2014), "Supply Chain Management: It's All About the Journey, Not the Destination", Journal of Supply Chain Management, Vol. 50, No. 1, pp. 8-20.

Fine, A. (1984), Scientific Realism. Berkeley: University of California Press.

Flynn, B., Huo, B. and Zhao, X. (2010), "The impact of supply chain integration on performance: a contingency and configuration approach", Journal of Operations Management, Vol. 28, No. 1, pp. 58-71.

Freise, M. and Seuring, S. (2015), "Social and environmental risk management in supply chains: a survey in the clothing industry", Logistics Research, Vol. 8, No. 1, pp.2-12.

Galperin, B., Bennett, R. and Aquino, K. (2010), "Status differentiation and the protean self: A social-cognitive model of unethical behaviour in organizations", Journal of Business Ethics, Vol. 98, pp. 407-424.

Gligor, D. and Autry, C. (2012). The role of personal relationships in facilitating supply chain communications: A qualitative study. Journal of Supply Chain Management, Vol. 48, No. 1, pp. 24-43.

Gligor, D. and Holcomb, M. (2013). The role of personal relationships in supply chains: An exploration of buyers and suppliers of logistics services. International Journal of Logistics Management, Vol. 24, No. 3, pp.328-355. 
Granovetter, M. (1985), "Economic action and social structure: The problem of embeddedness", American Journal of Sociology, Vol. 91, No. 3, pp.481-510.

Greenhalgh, T., Robert, G., Macfarlane, F., Bate, P., Kyriakidou, O. and Peacock, R. (2005), "Storylines of research in diffusion of innovation: a meta-narrative approach to systematic review”, Social Science \& Medicine, Vol. 61, No. 2, pp. 417-430.

Guetzkow, H. and Gyr, J. (1954), "An analysis of conflict in decision-making groups", Human Relations, Vol. 7, No. 3, pp.367-382.

Hafer, C., Begue, L., Choma, B. and Dempsey, J. (2005), "Belief in a Just World and Commitment to Long-Term Deserved Outcomes", Social Justice Research, Vol. 18, No. 4, pp. 429-444.

Hansson, S. (1996), “What is philosophy of risk?” Theoria, Vol. 62, No. 1-2, pp. 169-186.

Hansson, S. (1999), “A philosophical perspective on risk", Ambio, Vol. 28, No. 6, pp. 539542.

Hansson, S. (2010), "Risk: objective or subjective, facts or values", Journal of Risk Research, Vol. 13, No. 2, pp. 231-238.

Harms, P., Spain, S. and Hannah, S. (2011). Leader development and the dark side of personality. The Leadership Quarterly, Vol. 22, pp. 495-509.

Higgs, M. (2009), “The Good, the Bad and the Ugly: leadership and narcissism”, Journal of Change Management, Vol. 9, No. 2, pp. 165-178.

van Hoek, R., Chatham, R. and Wilding, R. (2002), "Managers in supply chain management, the critical dimension", Supply Chain Management, Vol. 7, No. 3/4, pp.119-125.

Holweg, M. and Pil, F. (2008), "Theoretical perspectives on the coordination of supply chains", Journal of Operations Management, Vol. 26, No. 3, pp. 389-406.

Horny, K. (1950), Neurosis and Human Growth: the struggle toward self-realization. New York: W.W. Norton. 
Jagosh, J., Salsberg, P., Macaulay, A., and Bush, P. (2011), Realist Review: An Introduction, Paper presented at the Canadian Public Health Association (CPHA) Meetings, Montreal, Canada.

Jakobwitz, S. and Egan, V. (2006), "The Dark Triad and Normal Personality Traits", Personality and Individual Differences, Vol. 40, pp. 331-339.

Johnston, A., McCutcheon, M., Stuart, F. and Kerwood, H. (2004), "Effects of Supplier Trust on Performance of Cooperative Supplier Relationships", Journal of Operations Management, Vol.22, No. 1, 23-38

Johnson, J., Dooley, K., Hyatt, D. and Hutson, A. (2018), “Cross - sector relations in global supply chains: A social capital perspective", Journal of Supply Chain Management, DOI: https://doi.org/10.1111/jscm.12166

Juttner, U., Peck, H. and Christopher, M. (2003), "Supply chain risk management: outlining an agenda for future research", International Journal of Logistics: Research \& Applications, Vol. 6, No. 4, pp. 197-210.

Juttner, U. (2005), "Supply chain risk management: understanding the business requirements from a practitioner perspective", International Journal of Logistics Management, Vol. 16, No. 1, pp. 120-141.

Kanda, A. and Deshmukh, S. 2008. Supply chain coordination: perspectives, empirical studies and research directions. International Journal of Production Economics, Vol. 115, No. 2, pp. 316-335.

Katsikopoulos, K. and Gigerenzer, G. 2013. Behavioural operations management: A blind spot and a research program. Journal of Supply Chain Management ${ }_{2}$ Vol. $_{4}{ }_{2}$ No. 1, pp. 3-7.

Khan, O. and Burnes, B. 2007. Risk and supply chain management: creating a research agenda. International Journal of Logistics Management, Vol. 18, No. 2, pp. 197-216.

Kilubi, I. (2016), "Investigating current paradigms in supply chain risk management-a bibliometric study", Business Process Management Journal, Vol. 22, No. 4, pp. $662-$ 692. 
Klassen, R. and Vereecke, A. (2012), "Social issues in supply chains: Capabilities link responsibility, risk (opportunity), and performance", International Journal of Production Economics, Vol. 140, No. 1, pp.103-115.

Kozan, M., Wasti, S. and Kuman, A. (2006), "Management of Buyer-Supplier Conflict: The Case of the Turkish Automotive Industry", Journal of Business Research, Vol. 59, 662$\underline{670 .}$

Knemeyer, A. and Naylor, R. (2011), "Using behavioral experiments to expand our horizons and deepen our understanding of logistics and supply chain decision making”, Journal of Business Logistics, Vol. 32, No. 4, pp. 296-302.

Knight, K. (1999), Liberalism and Conservatism. In J.P. Robinson, P.R. Shaver and L.S. Wrightsman. Measures of Political Attitudes. San Diego, CA: Academic Press.

Lam, P. and Chin, K. (2005), "Identifying and Prioritizing Critical Success Factors for Conflict Management in Collaborative New Product Development", Industrial Marketing Management, Vol. 34, No. 8, 761-772.

Lam, P., Chin, K. and Pun, F. (2007), "Managing Conflict in Collaborative New Product Development: a Supplier Perspective", International Journal of Quality \& Reliability Management, Vol.24, No. 9, 891-907.

Leamy, M., Bird, V., Le Boutillier, C., Williams, J. and Slade, M. (2011), “Conceptual framework for personal recovery in mental health: systematic review and narrative synthesis", British Journal of Psychiatry, Vol. 199, No. 6, pp. 445-452.

Lingnau, .V and Dehne-Niemann, T. (2015), When managing is damaging - corporate psychopaths and their potential impact on stakeholders' achievement of objectives in the global supply chain. In: Vorbohle K, Quandt JH, Schank C (eds) Verantwortung in der globalen Wertschöpfung, pp 71-92

Lopez, J. and Potter, G. (2001), After Postmodernism: an introduction to critical realism. London: The Athlone Press.

Lopreato, J. (1980), "Pareto's Sociology in a Sociobiological Key”, Revue Européenne des Science Sociales, Vol. 18, No. 51, pp. 133-162. 
Lupton, D. (1999), Risk. New York: Routledge

Lowenfeld, H. (1945), “The Authoritarian Character Structure”, Psychoanalytic Quarterly, Vol. 14, pp. 284-285.

Machiavelli, N. (1513/1961), The Prince. trans. G. Bull. Harmondsworth: Penguin Books.

Marshall, A. (2007), Vilfredo Pareto's Sociology: a framework for political psychology. Aldershot: Ashgate.

Marshall, A. and Guidi, M. (2012), The Idea of a Sociology of Risk and Uncertainty: Insight from Pareto. In J. V. Femia and A. Marshall (eds) Vilfredo Pareto: beyond Disciplinary Boundaries, Ashgate, Farnham, pp. 85-110.

Marshall, A. and Ojiako, U. (2010), "From the myth of Prometheus to strategic resilience: two cognitive paradigms linking risk and innovation", Prometheus, Vol. 28, No. 4, pp. 343-360.

Marshall, A. and Ojiako, U. (2013), "Managing risk through the veil of ignorance. Journal of Risk Research, Vol. 16, No. 10, pp. 1225-1239.

Marshall, A. and Ojiako, U. (2015), “A realist philosophical understanding of entrepreneurial risk-taking”, Society \& Business Review, Vol. 10, No. 2, pp. 178-193.

Maccoby, M. (2003), The Productive Narcissist: the promise and peril of visionary leadership. Broadway Books, New York.

Mangan, J. and Christopher, M. (2005), "Management development and the supply chain manager of the future", International Journal of Logistics Management, Vol. 16, No. 2, pp.178-191.

McDermott, O., Crellin, N., Ridder, H., and Orrell, M. (2013), "Music therapy in dementia: a narrative synthesis systematic review", International Journal of Geriatric Psychiatry, Vol. 28, No. 8, pp. 781-794.

Merkelsen, H. (2011), "Institutionalised Ignorance as a Precondition for Rational Risk Expertise", Risk Analysis: An International Journal, Vol. 31, No. 7, pp. 1083-1094. 
Murphy, P. and Poist, R. (2007), "Skill requirements of senior-level logisticians: a longitudinal assessment”, Supply Chain Management: An International Journal, Vol. 12, No. 6, pp. 423-431.

Narasimhan, R. and Talluri, S. (2009), "Perspectives on risk management in supply chains", Journal of Operations Management 27 (2): 114-118.

Oliver, S., Harden, A., Rees, R., Shepherd, J., Brunton, G., Garcia, J. and Oakley, A. (2005), "An emerging framework for including different types of evidence in systematic reviews for public policy", Evaluation, Vol. 11, No. 4, pp. 428-446.

Paulhus, D. and Williams, K. (2002), "The Dark Triad of Personality: Narcissism, Machiavellianism and Psychopathy”, Journal of Research in Personality, Vol. 36, pp. $556-563$

Pareto, V. (1935), The Mind and Society. Jonathan Cape.

Peck, H. (2005), "Drivers of supply chain vulnerability: an integrated framework", International Journal of Physical Distribution \& Logistics Management, Vol. 35, No. 4, pp. 210-232.

Pelled, L. and Adler, P. (1994), "Antecedents of intergroup conflict in multifunctional product development teams: A conceptual model", IEEE Transactions on Engineering Management, Vol. 41, No. 1, pp.21-28.

Pelled, L., Eisenhardt, K. and Xin, K. (1999), "Exploring the black box: An analysis of work group diversity, conflict and performance", Administrative Science Quarterly, Vol. 44, No. 1, pp.1-28.

Peters, L., Pressey, A., Vanharanta, M. and Johnston, W. (2013), “Constructivism and critical realism as alternative approaches to the study of business networks: Convergences and divergences in theory and in research practice", Industrial Marketing Management, Vol. 42, No. 3, pp. 336-346.

Pfohl, H., Köhler, H. and Thomas, D. (2010), "State of the art in supply chain risk management research: empirical and conceptual findings and a roadmap for the implementation in practice", Logistics Research, Vol. 2, No. 1, pp.33-44. 
Popay, J., Roberts, H., Sowden, A., Petticrew, M., Arai, L., and Rodgers, M., et al. (2006), Guidance on the conduct of narrative synthesis in systematic reviews: A product from the ESRC methods programme, http://www.lancs.ac.uk/shm/research/nssr/research/dissemination/publications.php, accessed 03/09/17.

$\underline{\text { Rao, S. and Goldsby, T. (2009), "Supply chain risks: a review and typology", International }}$ Journal of Logistics Management, Vol. 20, No. 1, pp.97-123.

Reed, I. (2008), “Justifying Sociological Knowledge: From Realism to Interpretation", Sociological Theory, Vol. 26, No. 2, pp. 101-129.

$\underline{\text { Reinecke, J., Donaghey, J., Wilkinson, A. and Wood, G. (2018), "Global supply chains and }}$ social relations at work: Brokering across boundaries", Human Relations, Vol. 71, No. $\underline{4, \text { In Press. }}$

Rossetti, C. and Choi, T. (2005), "On the dark side of strategic sourcing: experiences from the aerospace industry", Academy of Management Executive, Vol. 19, No. 1, pp.46-60.

Rotaru, K., Churilov, L. and Flitman, A. (2014), "Can critical realism enable a journey from description to understanding in operations and supply chain management?", Supply Chain Management: An International Journal, Vol. 19, No. 2, pp. 117-125.

Sandberg, E. and Abrahamsson, M. (2010), "The role of top management in supply chain management practices", International Journal of Retail \& Distribution Management, Vol. 38, No. 1, pp. 57-69.

Sayer, A. (2000), Realism and social science. London: Sage.

Schorsch, T., Wallenburg, C.M. and Wieland, A. (2017), "The human factor in SCM: Introducing a meta-theory of behavioural supply chain management", International Journal of Physical Distribution \& Logistics Management, Vol. 47, No. 4, pp.238-262.

Seth, A. (2002), Competitive Foraging, Decision-Making, and the Ecological Rationality of the Matching Law. Proceedings of the Seventh International Conference on Simulation of Adaptive Behaviour: From animals to animats, pp. 359-368. 
Sharif, A. and Irani, Z. (2012), "Supply chain leadership", International Journal of Production Economics, Vol. 140, No. 1, pp. 57-68.

Simon, H. (1990), “Invariants of Human Behaviour”, Annual Review of Psychology, Vol. 41, pp. 1-19.

Stank, T., Dittmann, J. and Autry, C. (2011), “The new supply chain agenda: a synopsis and directions for future research", International Journal of Physical Distribution \& Logistics Management, Vol. 41, No. 10, pp. 940-955.

Starr, C. (1980), Introductory Remarks in Societal Risk Assessment: How Safe is Safe Enough? 4 (R. Schwing and W. Albers eds.)

Stock, J. (1997), "Applying theories from other disciplines to logistics", International Journal of Physical Distribution \& Logistics Management, Vol. 27, No. 9/10, pp. 515-539.

Stock, J., Boyer, S. and Harmon, T. (2010), "Research opportunities in supply chain management", Journal of the Academy of Marketing Sciences, Vol. 38, pp. 32-41.

Stock, J. (2009), “A research view of supply chain management: Developments and topics for exploration”, ORiON, Vol. 25, No. 2, pp. 147-160.

Tang, C. (2006), "Perspectives in supply chain risk management", International Journal of Production Economics, Vol. 103, No. 2, pp. 451-488.

Taylor-Gooby, P. and Zinn, J. (2006), "Current Directions in Risk Research: new directions in psychology and sociology", Risk Analysis: An International Journal, Vol. 26, No. 2, pp. 397-411.

Thompson, P. (1986), "The Philosophical Foundations of Risk", Southern Journal of Philosophy, Vol. 24, No. 2, pp. 273-286.

Thompson, P. (1990), "Risk Objectivism and Risk Subjectivism: when are risks real?" Risk: Health, Safety and the Environment, Vol. 1, No. 3, pp. 3-22.

Todd, P. and Gigerenzer, G. (2007), "Environments that make us smart: ecological rationality", Current Directions in Psychological Science, Vol. 16, No. 3, pp. 167-171. 
Tokar, T. (2010), "Behavioural research in logistics and supply chain management", International Journal of Logistics Management, Vol. 21, No. 1, pp. 89-103.

Tokar, T., Aloysius, J., Williams, B. and Waller, M. (2014), "Bracing for demand shocks: An experimental investigation", Journal of Operations Management, Vol. 32, No. 4, pp.205-216.

Wagner, S. and Bode, C. (2008), "An empirical examination of supply chain performance along several dimensions of risk", Journal of Business Logistics, Vol. 29, No. 1, pp.307-325.

Wieland, A., Handfield, R. and Durach, C. (2016), "Mapping the landscape of future research themes in supply chain management", Journal of Business Logistics, Vol. 37 No. 3, pp. $\underline{1-8 .}$

Wild, J. (1947), “What is Realism?” Journal of Philosophy, Vol. 44, No. 6, pp. 148-158.

Wilson, G. and Patterson, J. (1970), The Conservatism Scale. Windsor, England: National Foundation for Educational Research.

Wynne, B. (1989), Frameworks of Rationality in Risk Management: towards the testing of naive sociology. In J. Brown (ed), Environmental Threats: perception, analysis and management. London: Belhaven Press, pp. 33-47.

Youn, S., Yang, M. and Hong, P. (2012), "Integrative leadership for effective supply chain implementation: An empirical study of Korean firms", International Journal of Production Economics, Vol. 139, No. 1, pp. 237-246.

Zeng, B. and Yen, B. (2017), "Rethinking the role of partnerships in global supply chains: A risk-based perspective", International Journal of Production Economics, Vol. 185, pp.52-62.

Zinn, J. (2008), "Heading into the Unknown: everyday strategies for managing risk and uncertainty", Health, Risk and Society, Vol. 10, No. 5, pp. 439-450. 